Gi respons på artikler gjennom artiklenes kommentarfelt på tidsskriftet.no. Innleggene publiseres fortløpende på Tidsskriftets nettside og et utvalg av innleggene publiseres også i papirutgaven i spalten «Brev til redaktøren».

Redaksjonen forbeholder seg retten til å foreta redaksjonelle endringer.

Forfattere av vitenskapelige artikler har tilsvarsrett, jf. Vancouver-gruppens regler.

\section{Re: Alle selvmord skyldes ikke behandlingssvikt}

Det tidligere fagrådet for psykisk helsevern i Helse Sørøst påpeker at selvmordsforebyggende arbeid fokuserer for mye på selvmordsrisikovurderinger og for lite på god behandling (1). Statens helsetilsyn ønsker dette innspillet velkommen. Mangler ved utredning, behandling og kontinuitet $\mathrm{i}$ behandlingen er hyppige funn ved våre undersøkelser etter selvmord.

Artikkelforfatterne hevder at Statens helsetilsyn har «liten kapasitet, og de undersøker bare en svært liten andel av de alvorlige hendelsene som meldes». Dette medfører ikke riktighet. Alle de 414 varslede alvorlige hendelsene i 2014 ble undersøkt gjennom direkte kontakt med helseforetakene. Pasientens journal undersøkes når det er behov for ytterligere informasjon. En samlet stab av helsepersonell (som i 2015 ble styrket med to psykiatere), jurister og ledere gjennomgår innhentet informasjon for hvert varsel og vurderer hva som er hensiktsmessig oppfølging. I hyppige møter med fylkesmennene velges forskjellige tilsynsmetoder. Stedlig tilsyn er en av disse, og kriteriene for å velge dette er strenge (2).

201 av fjorårets varsler kom fra psykisk helsevern og tverrfaglig spesialisert rusbehandling, og 157 av disse omhandlet selvmord og dødelige overdoser, som er tilsvarende antall meldt til Kunnskapssenteret (3). Dette kan være uttrykk for at Helsetilsynets varselordning er godt kjent. I cirka $50 \%$ av disse varslene finner Statens helsetilsyn ikke tegn på vesentlig svikt $\mathrm{i}$ helsehjelpen som er gitt (2). Helsetilsynet planlegger å publisere innhentede behandlingsdata fra varsler som omhandler selvmord i perioden 2013-2015. Dette kan være interessant $\mathrm{i}$ det overordnede selvmordsforebyggende arbeidet.

Forfatterne skriver: «Rapportene kommer vanligvis sent, oftest et halvt eller ett år etter hendelsen, da det meste er glemt. De får derfor liten betydning for evalueringen blant fagfolk lokalt». Statens helsetilsyn har raskere saksbehandlingstid som mål. I saker med alvorlig svikt i helsetjenesten er det imidlertid avgjørende at rettssikkerheten til pasienter, pårørende og involvert helsepersonell ivaretas. Dette er tidkrevende arbeid. Vår erfaring er at de forskjellige partene ønsker grundighet framfor raskhet.

Fagrådet peker på forskning i Storbritannia der alle registrerte selvmord kobles mot andre registre av ulike slag. Forskningen har utfordringer med forsinkelser i registrene og er beheftet med feilkilder siden det kun er involvert helsepersonell som vurderer eventuell svikt (4). Slik kombinert register - og behandlingsforskning er viktig for å følge selvmord hos personer i psykisk helsevern over tid slik at risikoreduserende tiltak på systemnivå kan iverksettes, men kan slik vi ser det ikke fungere som en «Havarikommisjon» lik de vi har i Norge innen andre felt enn helse.

\section{Anders Gaasland \\ ang@helsetilsynet.no \\ Ingrid A. Havnes \\ Morten Venberget \\ Jan Fredrik Andresen}

Anders Gaasland er fagsjef i Statens helsetilsyn.

Ingen oppgitte interessekonflikter.

Ingrid A. Havnes er ph.d. og seniorrådgiver i Statens helsetilsyn.

Ingen oppgitte interessekonflikter.
Morten Venberget er seniorrådgiver i Statens helsetilsyn.

Ingen oppgitte interessekonflikter.

Jan Fredrik Andresen er direktør i Statens helsetilsyn.

Ingen oppgitte interessekonflikter.

Litteratur

1. Ness E, Fixdal T, Torper JL et al. Alle selvmord skyldes ikke behandlingssvikt. Tidsskr Nor Legeforen 2015; 135: 1342-3.

2. Med tilsynsblikk på alvorlige og uventede hendelser i spesialisthelsetjenesten. Rapport fra Helsetilsynet 5/2015. https://www.helsetilsynet.no/no/ Publikasjoner/Rapport-fra-Helsetilsynet/Rapport-Helsetilsynet-2015/ Med-tilsynsblikk-pa-alvorlige-og-uventede-hendelser-ispesialisthelsetjenesten/ (14.9.2015).

3. Arsrapport for uønskede hendelser i spesialisthelsetjenesten. Nasjonalt kunnskapssenter for helsetjenesten 2015. www.kunnskapssenteret.no/ publikasjoner/arsrapport-2014-for-meldeordningen-for-uonskede-hendelser-spesialisthelsetjenesten (14.9.2015).

4. The national confidential inquiry into suicide and homicide by people with mental illness. University of Manchester 2015. www.bbmh.manchester.ac.uk/ $\mathrm{cmhs} /$ research/centreforsuicideprevention/nci/ (14.9.2015).

\section{Re: Akuttmottaket trenger egne spesialister}

Det er et velkjent problem at pasienter i akuttmottakene ofte blir tatt i mot av leger med begrenset erfaring og kompetanse, noe som kan forsinke korrekt behandling. Det er derfor ikke vanskelig å være enig i kollegaene Bjørnsen og Ulebergs ønske om å heve kvaliteten på den medisinske diagnostikk og behandling som tilbys (1). Det er altså lett å være enig i diagnosen, men ikke i deres anbefalte løsning på problemet: En ny medisinsk spesialitet i akuttmedisin. Grunnen mener jeg er innlysende siden kompetansen allerede finnes, det er bare snakk om å organisere legeressursene slik at pasientene får nytte av den.

Hovedargumentet for den nye spesialiteten synes å være at alle andre land har den. Ja, men svært få land har et landsomfattende system med legevaktsleger som sorterer pasienter før de evt. legges inn i sykehus, slik vi har i Norge. Jeg synes således det er en drøy påstand at våre kolleger innen allmennmedisinen ikke er i stand til dette. Norsk selskap for akuttmedisin har laget en innholdsrik liste over den kompetanse som deres nye spesialitet skal beherske (2). Den er imponerende omfangsrik, men hvordan mener man at en lege skal klare å tilegne seg spesialistkompetanse innen alt dette? Eller er det snarere en liste over de mange akutte problemstillinger som en allmennlege kan møte i legevakt?

Den innlysende løsning er altså å få de eksisterende spesialiteter mer i fremste linje. En slik styrking trengs på mange sykehus. Leger i alle fagområder har dessuten behov for jevnlig oppdatering av akuttmedisinske kunnskaper og ferdigheter. Effekten av regelmessige teamøvelser for de som skal håndtere pasienter med livstruende situasjoner er veldokumenterte, og mange sykehus gjør dette. Likevel er det behov for å øke denne aktiviteten som ledd i kompetansebygging.

Min erfaring både i luftambulansetjenesten og andre deler av de prehospitale tjenestene, tilsier at tilgang på erfarne kolleger $\mathrm{i}$ indremedisin, kirurgi og anestesiologi, samt muligheter for billeddiagnostikk og laboratorietjenester, er det man trenger i akuttmottakene. Vi må derfor forbedre systemet vi har og ikke tro at flere spesialiteter vil løse problemet. 